\title{
26. CALCAREOUS-NANNOFOSSIL BIOSTRATIGRAPHY OF JAPAN TRENCH TRANSECT, DEEP SEA DRILLING PROJECT LEG 57
}

\author{
Bernard L. Shaffer, Gulf Research and Development Co., Houston, Texas
}

\section{INTRODUCTION}

As a continuation of the Japan Trench transect commenced by DSDP Leg 56,10 holes were drilled and 273 cores were recovered while occupying Sites 438,439 , 440, and 441 during Leg 57 (Figure 1). At Sites 438 and 439 , near the top of the trench inner wall, a principal biostratigraphic objective was to establish a Neogene reference section overlying a pronounced acoustic basement thought to represent continental crust extending outward to this slope environment. At Sites 440 and 441 , prime objectives were to distinguish, if present, admixtures of accreted oceanic and non-accreted slope materials, and to recognize repeated or missing sections resulting from the accretionary process.

This report summarizes the nannofossil biostratigraphy of the upper lower Miocene to Pleistocene sequences of Leg 57 cores. Insufficient occurrences in the lowermost Miocene, presumed upper Oligocene, and upper Cretaceous sequences at Sites 438 and 439 precluded age determinations for these intervals based on nannoliths. All but a few samples from Site 441 were barren, and in general Leg 57 nannofossil assemblages were too modified by dissolution and diagenesis to permit meaningful paleoclimatologic or paleobiogeographic conclusions to be drawn.

\section{METHODS}

This study is based on light microscopic examinations of both smear slides and slides prepared from a simple settling technique to enhance nannofossil concentrations. The latter technique was necessitated by the low frequency of nannofossil occurrences in the dominantly diatomaceous, hemi-terrigenous claystones and siltstones recovered on this leg. Of 1030 samples studied, $785(76.2 \%)$ were either barren or contained very rare, stratigraphically non-diagnostic nannoliths. Occurrence and abundance were recorded for all taxa encountered during microscopic examination, and such data for samples containing adequate assemblages are compiled for each hole.

Estimations of species abundances employed in this report follow the methods outlined by Hay (1970), with the slight modifications of Gartner (1972). Thus, the abundance of a species was determined with the light microscope at a magnification of $1560 \times$ as follows:
Abundant
(A) $=10-100$ specimens per field of view
Common

Few

Rare

(F) $=$ one specimen in 1-10 fields of view

(R) $=$ one specimen in $10-100$ fields of view

The letter symbols in parentheses above denote the corresponding abundance categories in the tabulations.

The preservation states of nannofossils are designated as follows:

$\mathrm{G}=$ Good preservation, little or no evidence of etching, dissolution, or overgrowth. All specimens readily identifiable.

$\mathbf{M}=$ Moderately good preservation, slight etching or overgrowth which has destroyed or obscures delicate structures and ornamentation. Most specimens readily identifiable.

$\mathrm{P}=$ Poor preservation, a majority of specimens strongly etched or overgrown, often fragmented. Diversity is low and species identification often difficult.

The nannoplankton species considered in this report are listed in Table 1.

\section{ZONATION}

The Miocene and Pliocene zonation employed for age determinations in this report is essentially that of Bukry (1975), although the recovered nannofossil assemblages were variously modified by latitudinal and dissolution effects which limited the degree of biostratigraphic resolution. Because of rare and sporadic distributions of many zonal indicators, several of Bukry's zones and subzones could not be determined. Similarly, zonal boundaries were sometimes difficult to place. With the exception of a few upper Miocene intervals, discoasters in particular were generally rare, and the absence to extreme rarity of ceratoliths rendered uppermost Miocene and lower Pliocene zonation attempts difficult or impossible. In the Miocene, the Discoaster deflandrei, Discoaster druggii, Helicosphaera kamptneri, Castinaster calyculus, Discoaster bellus, and Discoaster neorectus Subzones, and the Sphenolithus belemnos Zone, could not be recognized for lack of indicator taxa. The upper Oligocene section penetrated at Site 439 also was devoid of diagnostic species.

For the Pleistocene, the zonation of Gartner (1977) is preferred, but for reasons cited above his zonation could not be applied in its entirety. The Helicosphaera sellii Zone was not recognized, because the nominate species did not occur in the Pleistocene at Leg 57 sites. Gartner's zone of small Gephyrocapsa was not used in a formal sense, although the characteristic assemblage 

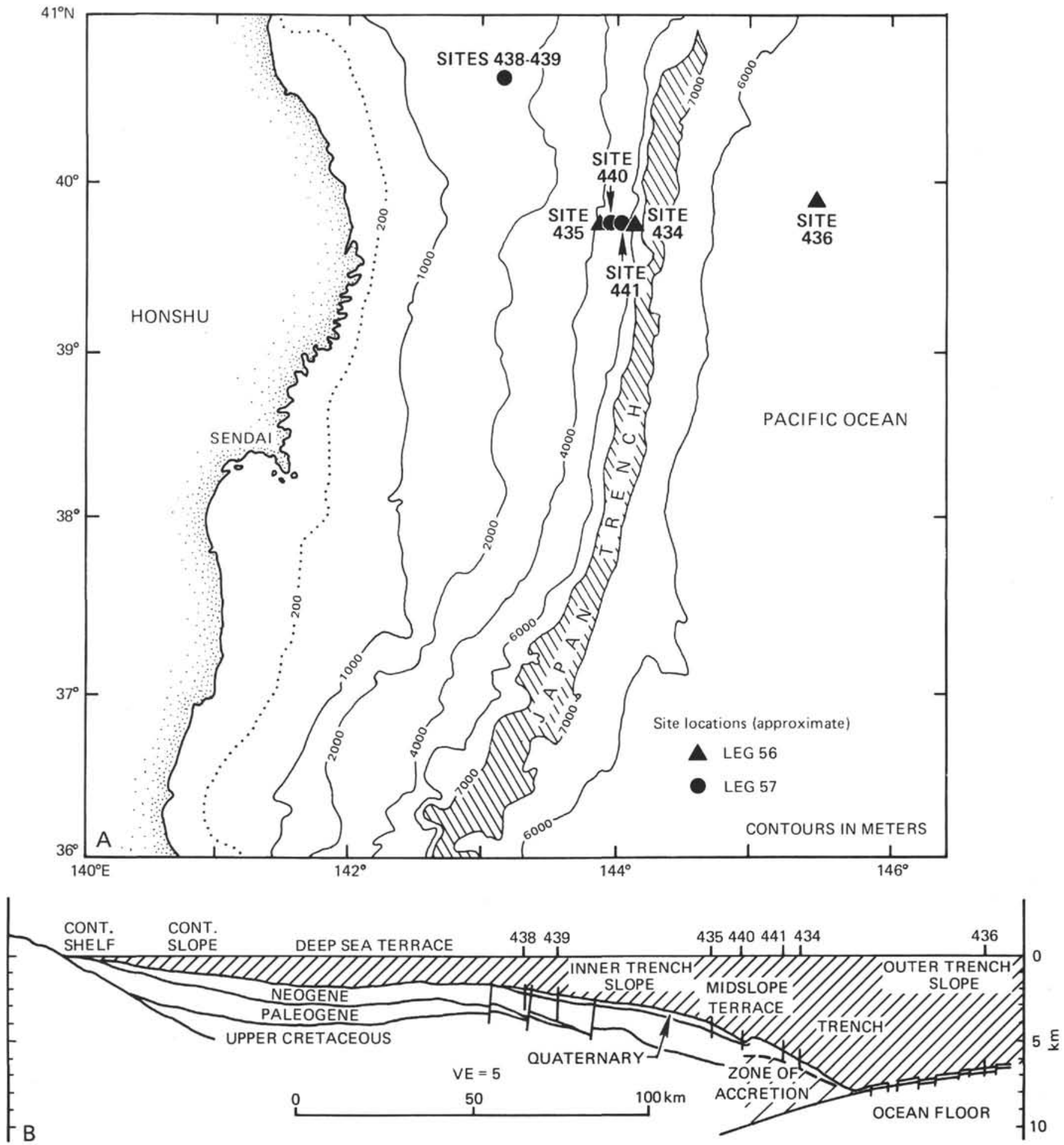

Figure 1. Location map and schematic cross section showing Leg 57 drill sites on Japan Trench Transect.

was present. As the small Gephyrocapsa "event" may prove to have paleooceanographic significance, its occurrence was noted. Emiliania huxleyi was rare, sporadic, and poorly preserved, and, with light microscopy, its first appearance could not be determined reliably. The Emiliania huxleyi Zone is here designated as the interval above the extinction datus of Pseudoemiliania lacunosa.

A summary of the Leg 57 nannofossil zonation, modified after Bukry (1975) and Gartner (1977), is presented in Figure 2. The zonal assignments of datable cores from Leg 57 holes are listed in Table 2. 
TABLE 1

List of Nannofossil Species Considered in This Report

Amaurolithus amplificus (Bukry and Percival) Gartner and Bukry, 1975 A. delicatus Gartner and Bukry, 1975

A. tricorniculatus (Gartner) Gartner and Bukry, 1975

Angulolithina arca Bukry, 1973

Braarudosphaera bigelowi (Gran and Braarud) Deflandre, 1947

Catinaster coalitus Martini and Bramlette, 1963

Ceratolithus acutus Gartner and Bukry, 1974

C. cristatus Kamptner, 1950

C. rugosus Bukry and Bramlette, 1968

Coccolithus pelagicus (Wallich) Schiller, 1930

C. miopelagicus Bukry, 1971

Crenalithus doronicoides (Black and Barnes) Roth, 1973

C. productellus Bukry, 1975

Cricolithus jonesi Cohen, 1965

Cyclicargolithus floridanus (Roth and Hay) Bukry, 1971

Cyclococcolithina leptopora (Murray and Blackman) Wilcoxon, 1970

C. macintyrei (Bukry and Bramlette) Bukry, 1973

Cyclolithella cricota (Gartner, 1967)

Discoaster asymmetricus Gartner, 1964

D. aulakos Gartner, 1967

D. bellus Bukry and Percival, 1971

D. berggrenii Bukry, 1971

D. braarudii Bukry, 1971

D. brouweri Tan Sin Hok, 1927

D. calcaris Gartner, 1967

D. challengeri Bramlette and Riedel, 1954

D. decorus (Bukry) Bukry, 1973

D. deflandrei Bramlette and Riedel, 1954

D. exilis Martini and Bramlette, 1963

D. hamatus Martini and Bramlette, 1963

D. intercalaris Bukry, 1971

D. kugleri Martini and Bramlette, 1963

D. neohamatus Bukry and Bramlette, 1969

D. neorectus Bukry 1971

D. pentaradiatus Tan Sin Hok, 1927

D. quinqueramus Gartner, 1969

D. signus Bukry, 1971

D. surculus Martini and Bramlette, 1963

D. tamalis Kamptner, 1967

D. triradiatus Tan Sin Hok, 1927

D. variabilis Martini and Bramlette, 1963

Discolithina japonica Takayama, 1967

D. multipora (Kamptner ex Deflandre, 1959) Martini, 1965

Emiliania huxleyi (Lowmann, 1902) Hay and Mohler, 1967

Gephyrocapsa caribbeanica Boudreaux and Hay, 1967

G. oceanica Kamptner, 1943

G. omega Bukry, 1973

Helicosphaera ampliaperta Bramlette and Wilcoxon, 1967

H. euphratis Haq, 1966

H. kamptneri (Hay and Mohler, 1967)

H. sellii (Bukry and Bramlette) Jafar and Martini, 1975

Minylitha convalis Bukry 1973

Pseudoemiliania lacunosa (Kamptner) Gartner, 1969

Reticulofenestra pseudoumbilica (Gartner) Gartner, 1969

Rhabdosphaera clavigera Murray and Blackman, 1898

Sphenolithus abies Deflandre 1954

$S$. heteromorphus Deflandre, 1953

S. moriformis (Brönnimann and Stradner) Bramlette and Wilcoxon, 1967

Triquetrorhabdulus carinatus Martini, 1965

T. rugosus Bramlette and Wilcoxon, 1967

\section{SITE SUMMARIES}

\section{Site 438}

Site 438 holes were drilled near the top of the trench inner wall, in 1565 meters of water. The principal objectives at the site were (1) to penetrate and date a pronounced seismic horizon that may represent the boundary of oceanic and continental crust between the Japan Trench and the continental shelf, and (2) to obtain a Neogene and (if present) a Paleogene geologic history of the continental shelf and slope.
Of 546 Site 438 samples prepared and studied, 398 $(73 \%)$ were barren or contained very rare and stratigraphically non-diagnostic nannofloras. In those samples that yielded adequate assemblages, nannofossils were rare to common, species diversities were generally low, preservation ranged from poor to moderate, with indications of dissolution and overgrowth, and the assemblages were mostly of extratropical aspect. Fluctuations of the relative influence of the ancient Kuroshio and Oyashio current systems; vertical fluctuations in the CCD, which in turn may be related to eustatic and climatic changes; diagenetic processes; and dilution by hemi-terrigenous material can be invoked as causal factors accounting for the generally rare and sporadic occurrences.

\section{Hole 438 (Table 3)}

Within the limits imposed by the quality of recovered nannofossil assemblages, the Pliocene to Pleistocene sequence of Hole 438 could be zoned and dated reasonably well. The interval encompassed by Core 1 and Section 2-6 belongs in the Emiliania huxleyi Zone, and the top of the Pseudoemiliania lacunosa Zone is placed in Section 2, CC on the basis of the extinction there of P. lacunosa. Samples in Sections 3-6 and 3,CC are within the lowermost-Pleistocene Cyclococcolithina macintyrei Zone. Cores 4 and 6 were not recovered, and samples within Core 5 were barren, except for $5, \mathrm{CC}$, which contained rare and non-diagnostic nannofossils. The Plio-Pleistocene boundary, which apparently is within the interval encompassed by Cores 4 through 6 , could not be determined. Section 7-1 contains very rare occurrences of Discoaster brouweri and is tentatively placed in the Discoaster brouweri/Discoaster pentaradiatus Zones. Sections 7-2 through 11-6 contain sporadic occurrences of $P$. lacunosa, D. brouweri, D. surculus, and $D$. variabilis. In the absence of Reticulofenestra pseudoumbilica and Sphenolithus abies, this sequence is assigned to the Discoaster surculus/Discoaster tamalis Zones. Samples from Core 12 were barren.

\section{Hole 438A (Table 4)}

Nannofloras were sufficiently developed in Hole $438 \mathrm{~A}$ to zone all but a few intervals of the middle-Miocene to Pleistocene sequence, although a lack of continuity of occurrences rendered zone boundary determinations difficult. Core 1 is assigned to the Emiliania huxleyi Zone. Pseudoemiliania lacunosa occurs at least as high as Section 2-3, and the top of the P. lacunosa zone is postulated to occur in the wash gap between Cores 1 and 2. Assemblages characteristic of Gartner's (1977) zone of small Gephyrocapsa were noted in 2,CC and $3, \mathrm{CC}$.

A minor hiatus involving the Plio-Pleistocene boundary is suspected, as the upper Pliocene $D$. brouweri Zone and the lower Pleistocene $C$. macintyrei Zone were not recognized. Section 4-6 through Core 6 is assigned to the Discoaster pentaradiatus Zone; the interval between 7-2 and 7,CC is within the Discoaster surculus Zone; and 8-2 through 10-5 is in the Discoaster tamalis Zone. The tentative top of the Reticulofenestra 


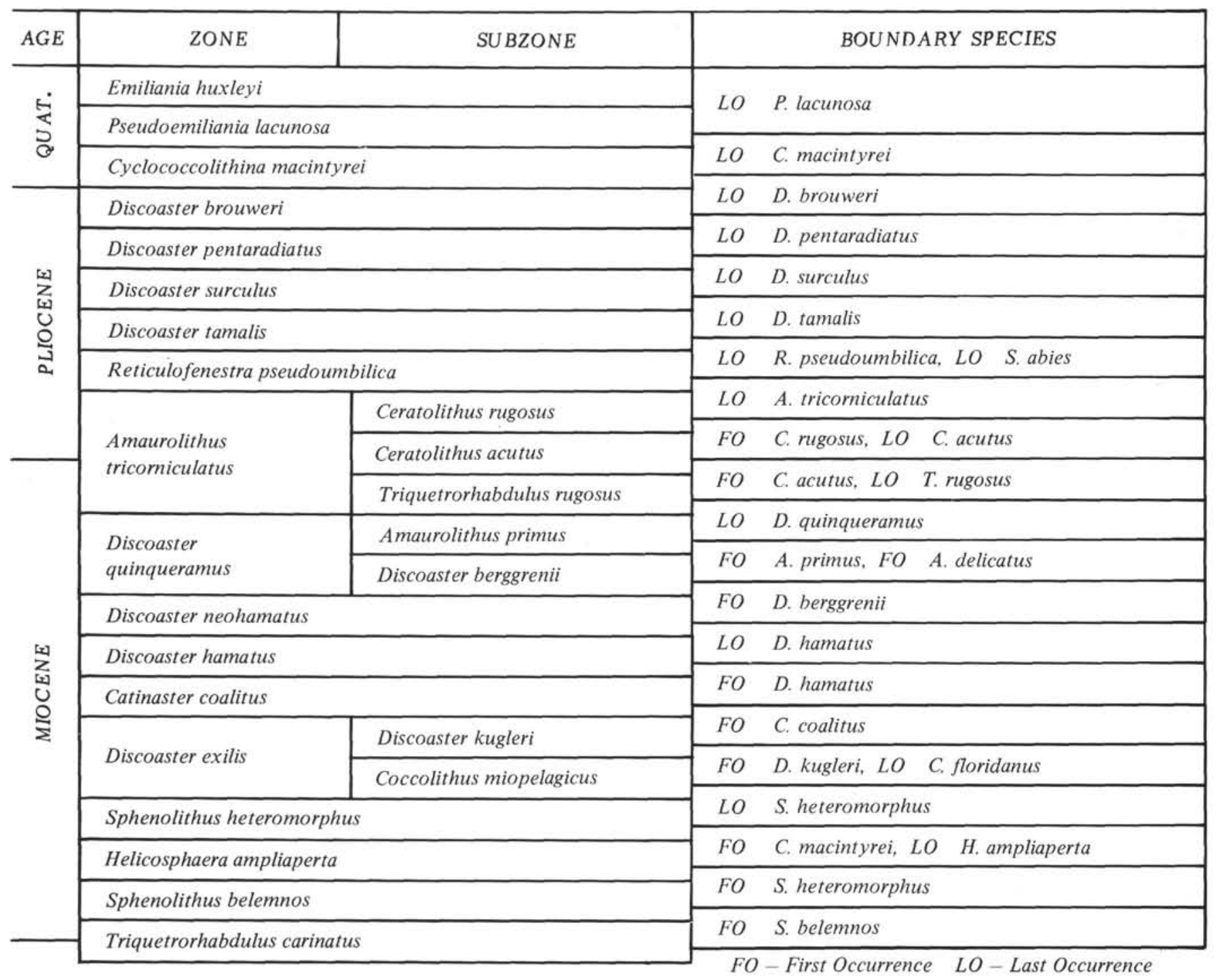

Figure 2. Calcareous-nannofossil zonation used for Leg 57 (modified after Bukry, 1975, and Gartner, 1977).

pseudoumbilica Zone in 10,CC approximates the top of the lower Pliocene. Ceratolith species used to define the top of the Ceratolithus rugosus Subzone were absent. Very rare occurrences of Ceratolithus acutus noted in 26-3 through 30,CC define the lowermost-Pliocene Ceratolithus acutus Subzone. The Miocene/Pliocene boundary, which could not be precisely determined, occurs between Cores 31 and 35 .

The upper Miocene Amaurolithus primus Subzone, as determined by the occurrence together of $A$. delicatus and Discoaster quinqueramus, occurs in 36,CC through 40-6, and the underlying Discoaster berggrenii Subzone is present in $40, \mathrm{CC}$ through $45, \mathrm{CC}$. Nannofloras assigned to the Discoaster neohamatus Zone (Cores 49 through 55) are generally rare and sporadic. The Discoaster hamatus Zone, the top of which approximates the top of the middle Miocene, is assigned to the interval between 56-1 and 61,CC. Sections 62,CC and 63,CC belong within the Catinaster coalitus Zone, and Section $65, \mathrm{CC}$ is included in the Discoaster kugleri Subzone. Sections 66, CC through 70, CC delineate the Cocco- lithus miopelagicus Subzone, as indicated by the presence of Cyclicargolithus floridanus. Samples from Cores 71 through 86 were barren or contained very rare, non-diagnostic species.

\section{Hole 438B (Table 5)}

In Hole 438B, a re-entry hole, Cores 1, 2, and 3 were taken at selected intervals for the purpose of establishing correlation points with Hole 438A. Core 1 is within the Discoaster neohamatus Zone and correlates with the interval in Hole 438A from Section 49-7 through Core 55. Core 2, assigned to the middle-Miocene Catinaster coalitus Zone, is coeval with Cores 62 and 63 of Hole 438A. Cores 3 and 4 were nannofossil barren.

Cores 5 through 11, characterized by rare to frequent occurrences of Sphenolithus heteromorphus, Discoaster deflandrei, and Cyclococcolithina macintyrei, are placed in the Sphenolithus heteromorphus Zone. Based on the occurrence of $S$. heteromorphus, very rare, atypical specimens of Helicosphaera ampliaperta, and the apparent absence of Cyclococcolithina macintyrei, Cores 
TABLE 2

Geological and Zonal Age of Leg 57 Cores from the Japan Trench

\begin{tabular}{|c|c|c|c|c|c|c|c|c|c|c|c|}
\hline ZONE & SUBZONE & 438 & $438 \mathrm{~A}$ & $438 B$ & 439 & 440 & $440 A$ & $440 B$ & 441 & $441 \mathrm{~A}$ & $441 B$ \\
\hline \multicolumn{2}{|c|}{ Emiliania huxleyi } & $1-2 / 2.4$ & $1 \mathrm{CC}$ & & & $1 \mathrm{cc} / 8 \mathrm{CC}$ & $2 \mathrm{cc} / 3 \mathrm{cc}$ & & & & \\
\hline \multicolumn{2}{|l|}{ Pseudioemitiania lacunosa } & $2 \mathrm{CC} / 3.4$ & $2 \cdot 3 / 3 \mathrm{CC}$ & & & & $4 \mathrm{CC} / 7 \mathrm{CC}$ & $1 \mathrm{CC} / 15-3$ & & & \\
\hline \multicolumn{2}{|c|}{ Cyclococcolithina macint yrei } & $3-6 / 3 c c$ & & & & & & $15 \mathrm{cc} / 19 \mathrm{cc}$ & & & \\
\hline \multicolumn{2}{|l|}{ Discoaster brouweri } & \multirow{2}{*}{$7-1$} & \multirow[b]{2}{*}{$4-6 / 6 \mathrm{CC}$} & & & & & \multirow{2}{*}{$20-2 / 22-3$} & & & \multirow{8}{*}{$2-2 ?$} \\
\hline \multicolumn{2}{|l|}{ Discoaster pentaradiatus } & & & & & & & & & & \\
\hline \multicolumn{2}{|l|}{ Discoaster surculus } & $7-2 / 11-6$ & $7.217 \mathrm{CC}$ & & & & & \multirow{2}{*}{\begin{tabular}{|l|}
$28 \mathrm{cc} / 32-4$ \\
$33-4 / 34-1$
\end{tabular}} & & & \\
\hline \multicolumn{2}{|c|}{ Disconster tamalis } & & $8 \cdot 2 / 10 \cdot 5$ & & & & & & & & \\
\hline \multicolumn{2}{|c|}{ Reticulofenestra pseudoumbilica } & & & & & & & $43,4149-2$ & \multirow{4}{*}{$\begin{array}{c}7-2 / 7 C C \\
?\end{array}$} & \multirow{2}{*}{$6 \mathrm{cC}$} & \\
\hline \multirow{3}{*}{$\begin{array}{l}\text { 1w-rarolithus } \\
\text { tricorriculatus }\end{array}$} & Ceratolithus rugosus & & $100 \mathrm{cc} 26-2$ & & & & & $43-4749-2$ & & & \\
\hline & Ceratolithus acutus & & $26 \cdot 3 / 30 \mathrm{cc}$ & & & & & & & & \\
\hline & Triquetrorhabcuius rugosus & & $31-1 / 35 \mathrm{cC}$ & & & & & $50 \mathrm{CC} / 57 \mathrm{cC}$ & & & \\
\hline \multirow{2}{*}{$\begin{array}{l}\text { Disi-master } \\
\text { guinquaramus }\end{array}$} & Amaurolithus primus & & $36 \mathrm{CC} / 40-6$ & & & & & $58-5 / 59-4$ & & \multirow{2}{*}{$13-1 / 14-1$} & \\
\hline & Discoaster berggrenif & & $40 \mathrm{CC} / 45 \mathrm{cC}$ & & $1-1 / 2 c c$ & & & $60 \cdot 3 / 71 \cdot 2$ & & & \\
\hline \multicolumn{2}{|l|}{ Discoaster neohamatus } & & $49-7 / 55 \mathrm{CC}$ & tCC & & & & & & & \\
\hline \multicolumn{2}{|l|}{ Dixcoaster hamatux } & & $56-1 / 61 \mathrm{CC}$ & & & & & & & & \\
\hline \multicolumn{2}{|l|}{ Catinaster coatitus } & & $62 \mathrm{cC} / 63 \mathrm{cc}$ & $2 \mathrm{cc}$ & $3 \mathrm{CC}$ & & & & & & \\
\hline \multirow{2}{*}{$\begin{array}{l}\text { Diveragster } \\
\text { rexilix }\end{array}$} & Discoaster kagteri & & $65 \mathrm{cc}$ & & & & & & & & \\
\hline & Coccolithus miopelagictux & & $66 \mathrm{cc} / 68 \mathrm{CC}$ & & & & & & & & \\
\hline \multicolumn{2}{|c|}{ Sphenolithus heteromorphus } & & & $5 \mathrm{CC} / 11 \mathrm{CC}$ & & & & & & & \\
\hline \multicolumn{2}{|c|}{ Helicosphiaera ampliaperta } & & & $12 / 15 \mathrm{CC}$ & $?$ & & & & & & \\
\hline \multicolumn{2}{|c|}{ Sphenntithus betemnos } & & & & & & & & & & \\
\hline \multicolumn{2}{|c|}{ Triquetrorhabdulus carinatus } & & & & $25 \cdot 2 / 29 \mathrm{CC} ?$ & & & & & & \\
\hline
\end{tabular}

12 through 15 are tentatively placed in the lower-Miocene Helicosphaera ampliaperta Zone. Cores 16 through 24 were barren of nannofossils.

\section{Site 439 (Table 5)}

Site 439 , just $5 \mathrm{~km}$ east of Site 438 , was selected as a more favorable location to complete the objectives of Site 438 , that is, to penetrate and date the acoustic basement. As at Site 438, nannofossil age and zone determinations were limited by sporadic occurrences, moderate to poor preservation, general rarity, and low species diversities. Ninety-six samples were examined; $83(86 \%)$ were barren or contained very rare, non-diagnostic nannofloras.

Cores 1 through 4 were spot cores taken for the purpose of establishing correlation points with Site 438 . Cores 1 and 2 are within the upper-Miocene Discoaster quinqueramus Zone; the apparent absence of ceratoliths supports placement of these cores within the Discoaster berggrenii Subzone. Cores 1 and 2 correlate with the interval in Hole 438A between 40,CC and 45,CC. Core 3 is assigned to the Catinaster coalitus Zone and is coeval with Cores 62 and 63 in Hole 438A and Core 2 in Hole 438B. No nannofossils were present in Core 4.

Rare occurrences of Sphenolithus heteromorphus, Discoaster deflandrei, and Cyclicargolithus floridanus in Cores 5 and 7 suggest an assignment of these cores to the Sphenolithus heteromorphus/Helicosphaera ampliaperta Zones (undifferentiated). This interval correlates in part with Cores 5 through 15 in Hole 438B. Cores 8 through 12,18 through 23 , and 27 through 28 were barren of nannofossils. Rare and sporadic assemblages consisting of Discoaster deflandrei, Cyclicargolithus floridanus, Reticulofenestra pseudoumbilica, and Coccolithus pelagicus characterize Cores 13 through 17 and
Core 24 . These intervals are tentatively considered undifferentiated lower Miocene. Extremely rare and poorly preserved nannoliths which are questionably identified as Triquetrorhabdulus carinatus were noted in 25-2 and $29, \mathrm{CC}$. This interval may belong in the $T$. carinatus Zone. Rare, diminutive, non-diagnostic Cenozoic coccoliths, which possibly reflect a stress environment, were the only nanofossils present in Cores 26 and 30 . Cores 30 through 39 were barren of nannofossils.

\section{Site 440}

Site 440 was drilled on the mid-slope terrace, $28 \mathrm{~km}$ landward from the trench axis, in 4509 meters of water. At this location, seismic data indicated a relatively undeformed Neogene sequence dipping gently landward above a strongly diffracting acoustic horizon.

From the three holes at Site 440, 327 samples were examined. Of these, $252(77 \%)$ were barren or contained very rare and non-diagnostic nannofloras. In productive samples, nannofossils were moderately well to poorly preserved and were very rare to abundant. The low species diversities probably reflect extra-tropical environmental influences and selective dissolution. Because of sporadic occurrences, a continuous nannofossil zonation was not possible, and zone and stage boundaries sometimes could not be delineated. Nannofossil recovery was enhanced somewhat by selective sampling of light-colored, calcareous mottles of unknown origin, occurring occasionally in otherwise barren matrices. Approximately 25 per cent of these mottles yielded adequate, sometimes abundant, nannofossil assemblages.

\section{Holes 440, 440A, 440B (Tables 6 and 7)}

All of Hole 440 (Cores 1 through 8 ) and Core 1 through Section 3,CC of Hole 440A lie above the 
TABLE 3

Nannofossil Occurrences at Hole 438

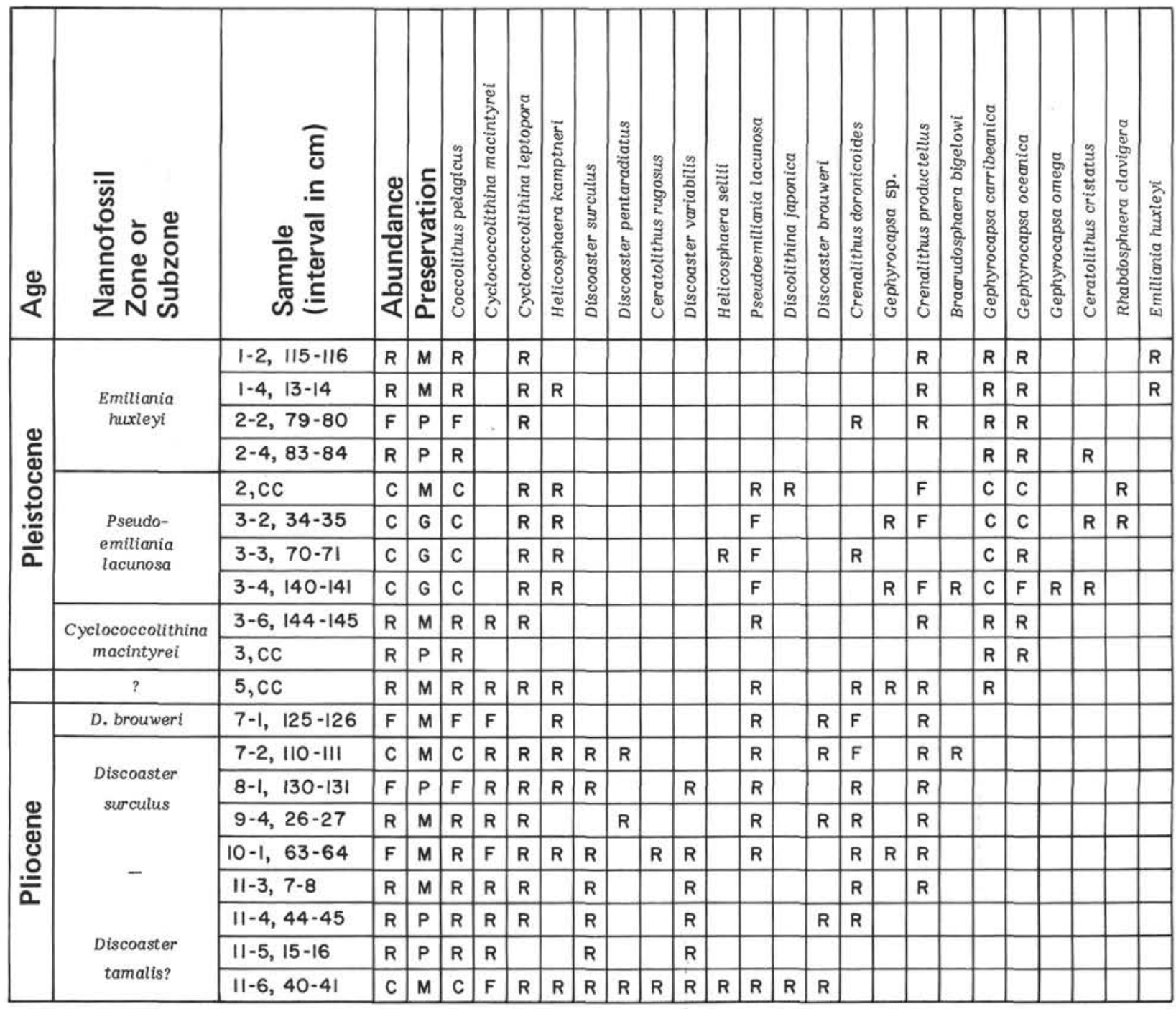

Pseudoemiliania lacunosa extinction datum (Emiliania huxleyi Zone). Reworked nannofossils, possibly attributable to mixing due to slumping, were noted in Core 1 of Hole 440. The intervals in 4,CC through 7,CC in Hole 440A and Core 1 through Section 15-3 in Hole 440B are included in the Pseudoemiliania lacunosa Zone. The lower boundary of this zone is uncertain, as the samples between Cores 8 and 15 (Hole 440B) are either barren or contain rare occurrences. The gephyrocapsid assemblage in $7, \mathrm{CC}$ (Hole 440B) is characterized by small individuals, and may correspond to Gartner's (1977) small Gephyrocapsa Zone. Section 15,CC (Hole 440B) is within the lower Pleistocene Cyclococcolithina macintyrei Zone, based on rare occurrences of that taxon.

In Hole 440B, Sections 20-2 through 22-3 are assigned to the uppermost-Pliocene Discoaster brouweri Zone; Cores 23 through 27 are barren or contain very rare, non-diagnostic nannoliths, and Sections 28,CC through 32-4 include the Discoaster surculus Zone. Rare occurrences of Discoaster tamalis were noted in 33-4, and samples from $34, \mathrm{CC}$ through $42, \mathrm{CC}$ were mostly barren. The top of the Reticulofenestra pseudoumbilica Zone is provisionally placed in Section 43-4, where $R$. pseudoumbilica and Sphenolithus abies have apparent last occurrences. Ceratoliths were too poorly represented to permit zonation of the lower-Pliocene sequence of Hole 440B. The base of the Ceratolithus rugosus Zone is placed in Section 49-2, based on the first occurrence there of $C$. rugosus. It was not possible to determine precisely the Miocene/Pliocene boundary, although the top of the Amaurolithus primus Subzone is well documented in 58-5. The first appearance of Amaurolithus delicatus in 59-4 marks the base of this subzone, and the Discoaster berggrenii Subzone occurs within the interval from Core 60 through Core 71.

\section{Site 441}

Site 441 is $15 \mathrm{~km}$ landward from the trench axis, on the lower part of the trench inner slope. The site was selected to penetrate the accretionary zone associated 
with the Japan Trench. Water depths at the three holes drilled at Site 441 ranged from 5640 to $5655 \mathrm{~m}$.

Of the 61 samples studied from Site 441 , only three intervals (Section 7-2 of Hole 441, and Cores 6, 13, and 14 of Hole 441A) contained age-diagnostic nannofossils. Most other samples were barren; a few yielded very rare, diminutive, non-diagnostic nannoliths. This site is presently well within the calcite-compensation range and apparently has been throughout the depositional history of the cored interval, with the exception of brief episodes in the upper Miocene and middle Pliocene.

Holes 441, 441A, 441B

A calcareous mottle within Section 7-2 of Hole 441 contained a common but poorly preserved, almost monospecific, nannoflora. Due to dissolution around shield peripheries and overgrowth in central areas, precise identification of the coccoliths was difficult. The dominant forms are probably referrable to Crenalithus doronicoides. They may also be small to intermediate forms of Reticulofenestra pseudoumbilica, and may represent populations occurring near the extinction level of that species. Larger forms more typical of $R$. pseudoumbilica were extremely rare. Equally rare components included Discoaster sp. cf. D. brouweri and Coccolithus pelagicus. This sample is tentatively placed within the upper part of the Reticulofenestra pseudoumbilica Zone (Pliocene).

Rare and poorly preserved nannofossils in $6, \mathrm{CC}$ of Hole 441A include Reticulofenestra pseudoumbilica.
An early-Pliocene age for this sample agrees with age determinations based on diatoms and radiolarians. Rare and moderately well to poorly preserved nannofloras in Sections 13-1 and 14-1 are assigned to the upper-Miocene Discoaster quinqueramus Zone, based on the presence of the nominate species.

Sections 1,CC, 2-2, and 2,CC of Hole 441B contain rare, poorly preserved small coccoliths (Crenalithus doronocoides and/or small Reticulofenestra pseudoumbilica) and discoaster fragments. No definite ages can be determined for Hole 441B on the basis of nannofossils.

In general, nannofossil evidence for Site 441 was insufficient to determine repeated zones or other indications of imbrication.

\section{REFERENCES}

Bukry, D., 1975. Silicoflagellate and coccolith stratigraphy, Deep Sea Drilling Project, Leg 29. In Kennett, J. P., Houtz, R. E., et al., Init. Repts. DSDP, 29: Washington (U.S. Govt. Printing Office), 845-872.

Gartner, S., 1972. Late Pleistocene calcareous nannofossils in the Caribbean and their interoceanic correlation. Palaeogeography, Palaeoclimatology, Palaeoecology, 12, 169191.

Gartner, S., 1977. Calcareous nannofossil biostratigraphy and revised zonation of the Pleistocene. Mar. Micropaleont., 2, $1-25$.

Hay, W. W., 1970. Calcareous nannofossils from cores recovered on DSDP Leg 4. In Bader, R. G., et al., Init. Repts. DSDP, 4: Washington (U.S. Govt. Printing Office), 455503. 
TABLE 4

Nannofossil Occurrences at Hole 438A

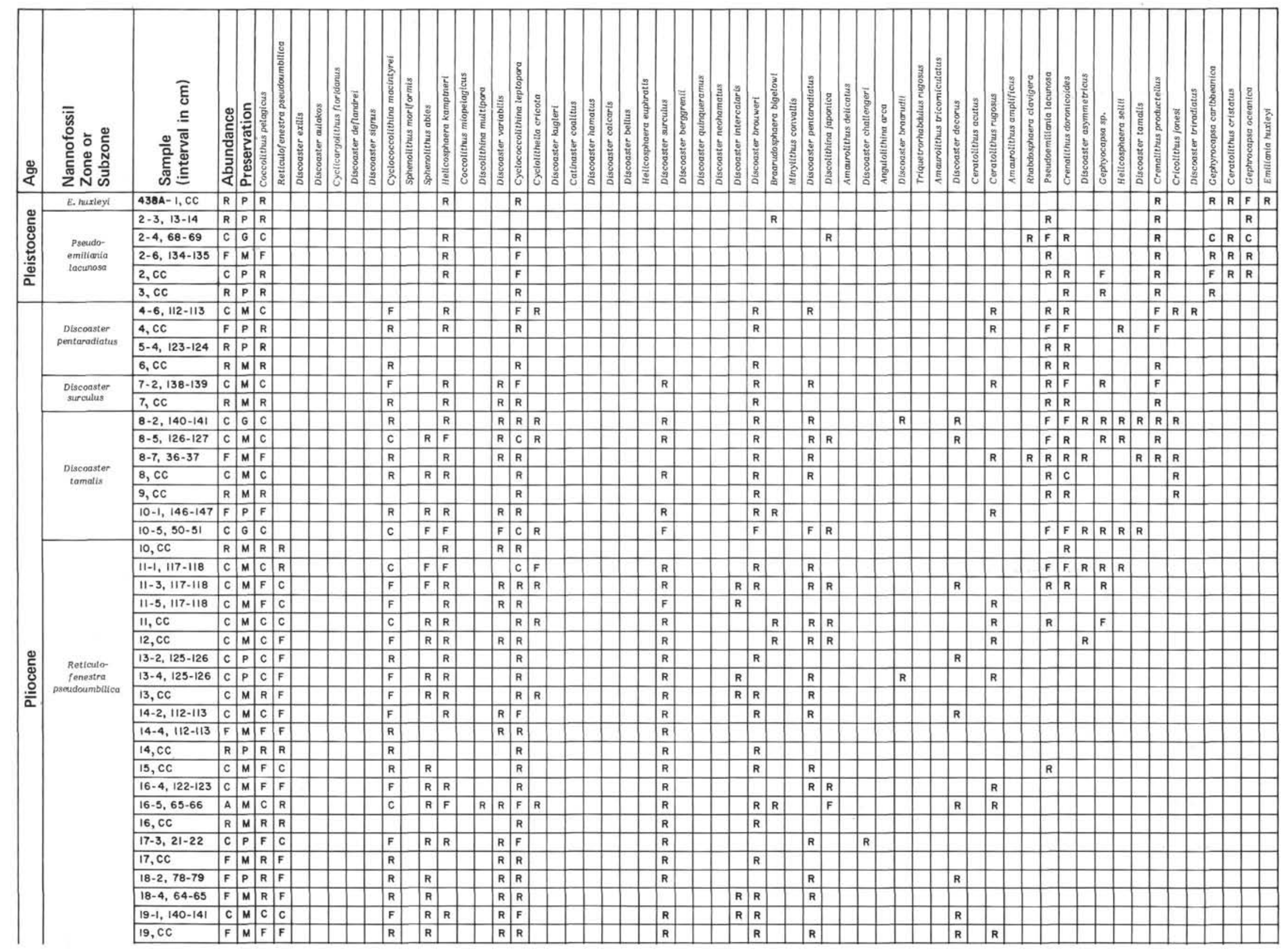




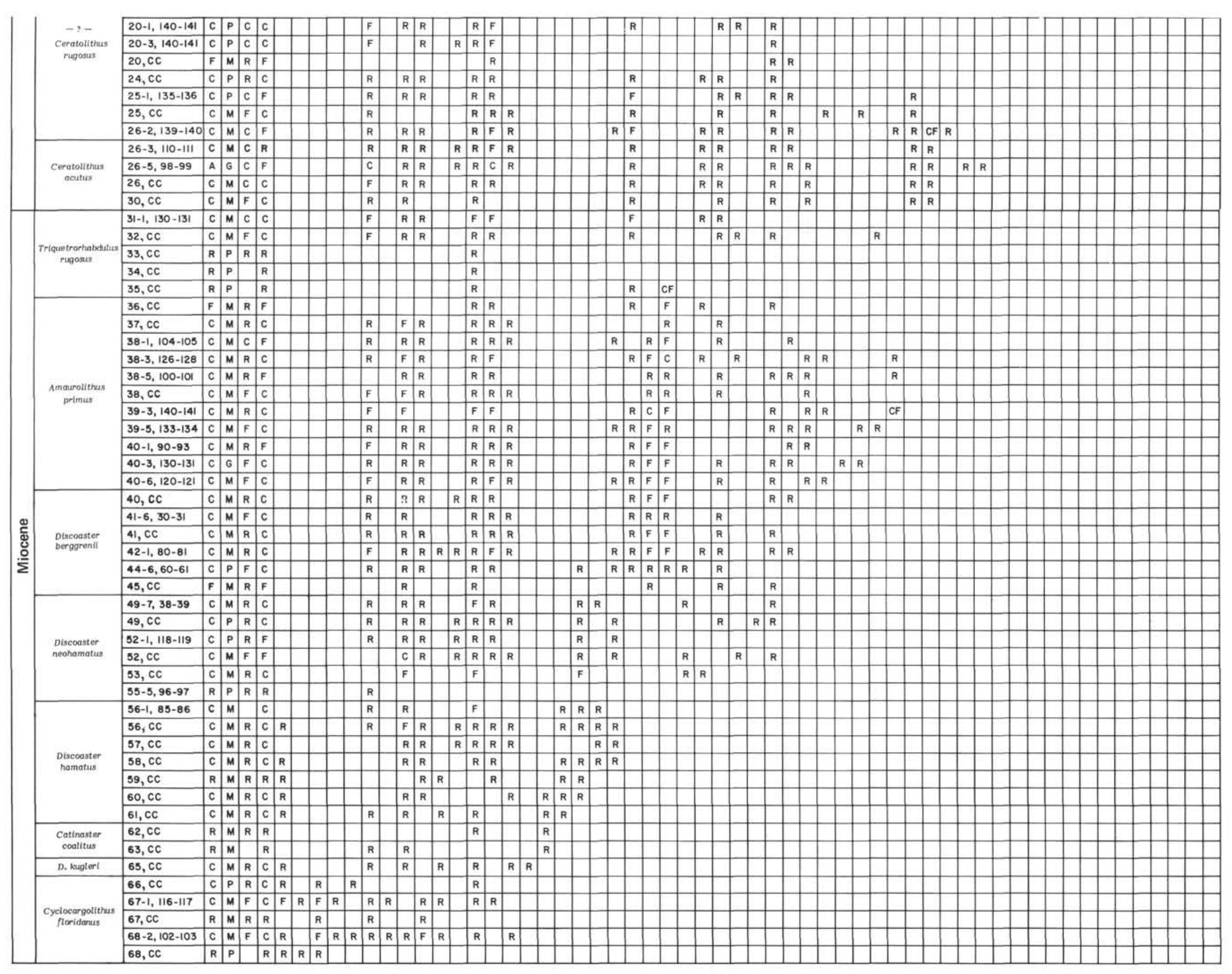


TABLE 5

Nannofossil Occurrences at Hole 438B and Site 439

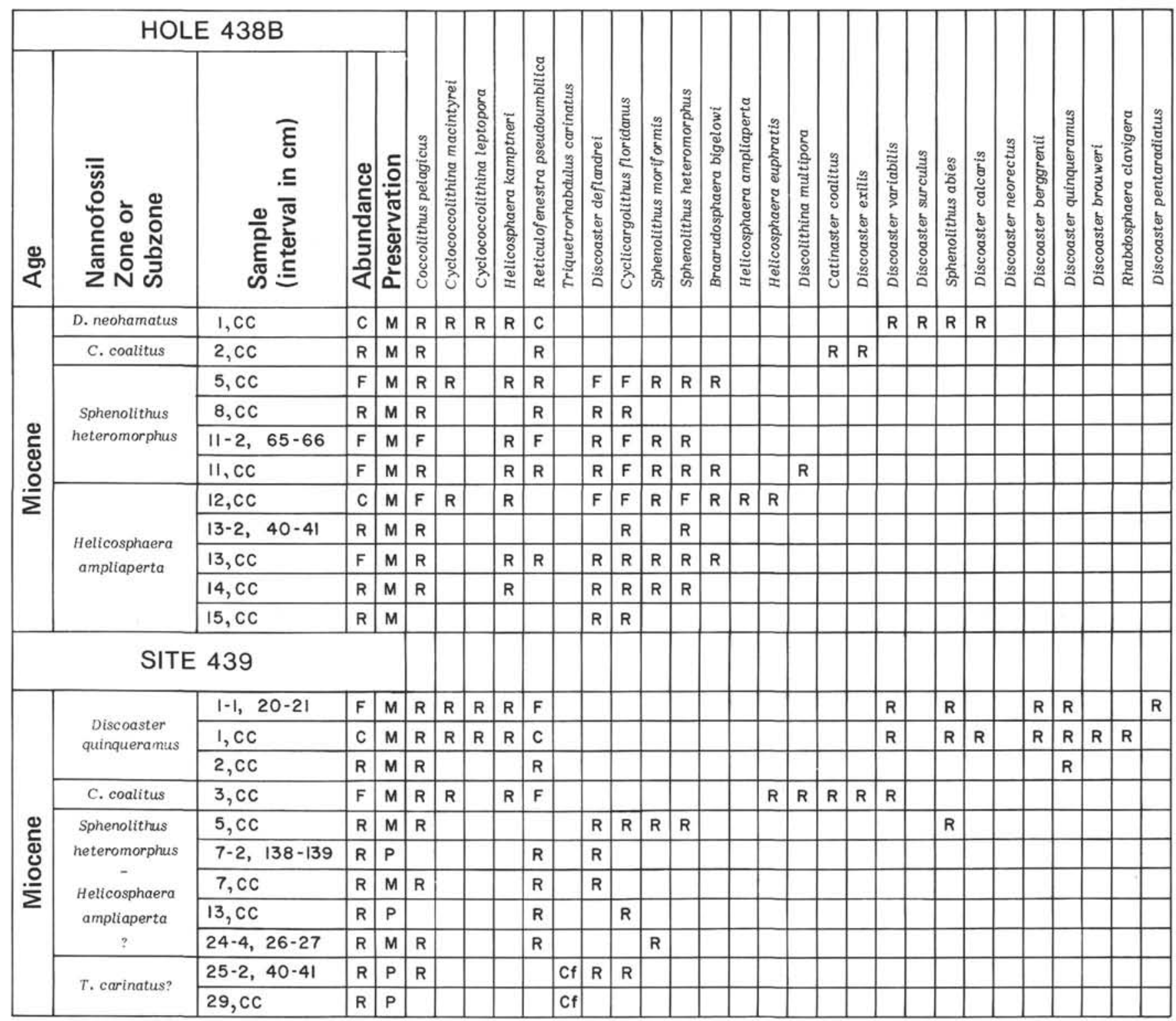


TABLE 6

Nannofossil Occurrences at Holes 440 and 440A

\begin{tabular}{|c|c|c|c|c|c|c|c|c|c|c|c|c|c|c|c|c|c|}
\hline \multicolumn{5}{|c|}{ HOLE 440} & & & & & & & & & & & & & \\
\hline 웜 & 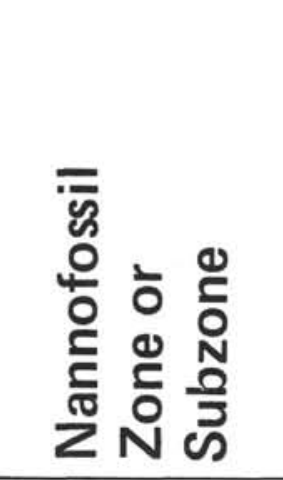 & 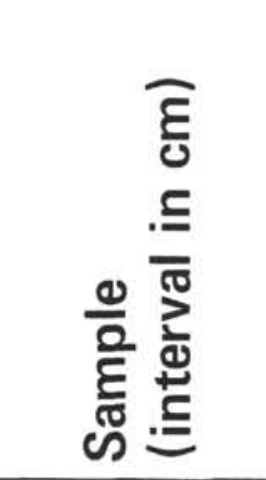 & $\begin{array}{l}\frac{0}{0} \\
\frac{1}{\pi} \\
\frac{\pi}{0} \\
\frac{5}{3} \\
\frac{0}{4}\end{array}$ & 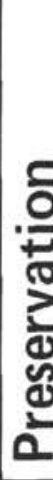 & 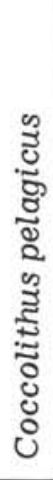 & 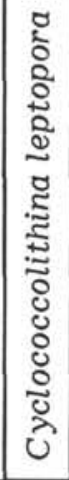 & 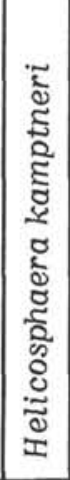 & 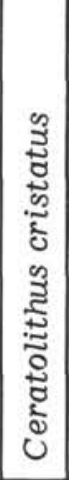 & 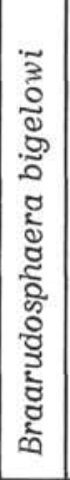 & 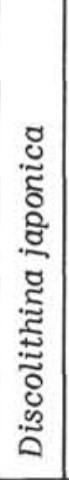 & 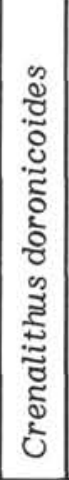 & 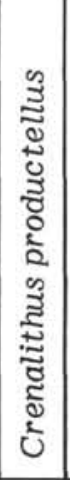 & 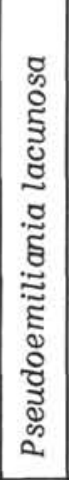 & 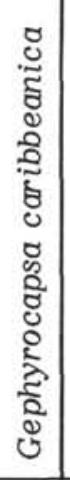 & 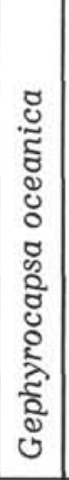 & 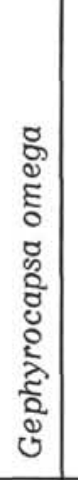 & \\
\hline \multirow{8}{*}{ 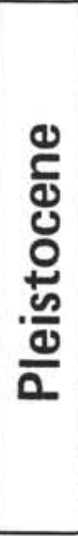 } & \multirow{8}{*}{$\begin{array}{c}\text { Emiliania } \\
\text { huxleyi }\end{array}$} & $1, \mathrm{CC}$ & C & M & $R$ & $\mathrm{R}$ & $R$ & $\mathrm{R}$ & & & & $R$ & & $c$ & C & & $\mathrm{R}$ \\
\hline & & $2, \mathrm{CC}$ & $\mathrm{F}$ & $\mathrm{P}$ & $R$ & $R$ & & & & & & $R$ & & $\mathrm{~F}$ & $\mathrm{~F}$ & & \\
\hline & & $3, C C$ & $\mathrm{R}$ & M & & & & & & & & & & $\mathrm{R}$ & $\mathrm{R}$ & & \\
\hline & & $4, \mathrm{CC}$ & $R$ & M & $\mathrm{R}$ & & $R$ & & & & & & & $\mathrm{R}$ & $R$ & & \\
\hline & & $5, \mathrm{CC}$ & $\mathrm{F}$ & $M$ & $R$ & $\mathbf{R}$ & & & & & & $R$ & & $\mathrm{~F}$ & $\mathrm{~F}$ & & $\mathrm{R}$ \\
\hline & & $6, \mathrm{Cc}$ & $R$ & $M$ & $R$ & & & & & & & & & $\mathrm{R}$ & $R$ & & \\
\hline & & $7, \mathrm{CC}$ & A & M & $\mathrm{F}$ & $\mathrm{R}$ & $R$ & & & & & $R$ & & $C$ & C & & \\
\hline & & $8, \mathrm{CC}$ & C & $\mathrm{P}$ & $R$ & $F$ & & & & & & & & $\mathrm{~F}$ & $\mathrm{~F}$ & & \\
\hline \multicolumn{5}{|c|}{ HOLE 440A } & & & & & & & & & & & & & \\
\hline \multirow{7}{*}{ 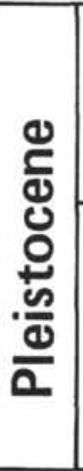 } & \multirow{3}{*}{$\begin{array}{l}\text { Emiliania } \\
\text { huxleyi }\end{array}$} & $2, C C$ & $\mathrm{~F}$ & M & $\mathrm{R}$ & $\mathrm{R}$ & & $\mathrm{R}$ & & & & $R$ & & $\mathrm{~F}$ & $\mathrm{~F}$ & & \\
\hline & & $3-3,22-23$ & C & M & $\mathrm{F}$ & $R$ & $\mathrm{R}$ & & & & & $R$ & & $\mathrm{~F}$ & $\mathrm{~F}$ & & \\
\hline & & $3, \mathrm{cc}$ & A & M & $\mathrm{F}$ & $\mathrm{R}$ & $\mathrm{R}$ & & & $\mathrm{R}$ & & $\mathrm{R}$ & & C & C & & \\
\hline & \multirow{4}{*}{$\begin{array}{l}\text { Pseudoemiliania } \\
\text { lacunosa }\end{array}$} & $4, C C$ & $\mathrm{~F}$ & M & $\mathrm{R}$ & $\mathrm{R}$ & $\mathrm{R}$ & & & & & $\mathrm{R}$ & $\mathrm{R}$ & $\mathrm{F}$ & $\mathrm{F}$ & & \\
\hline & & $5, \mathrm{CC}$ & $C$ & $M$ & $R$ & $R$ & $R$ & & & & & $\mathrm{R}$ & $\mathrm{F}$ & $\mathrm{F}$ & $C$ & & \\
\hline & & $6, \mathrm{Cc}$ & $C$ & $M$ & $R$ & $\mathrm{R}$ & & & & & $\mathrm{R}$ & $\mathrm{R}$ & $\mathrm{F}$ & $C$ & $c$ & $R$ & \\
\hline & & $7, \mathrm{CC}$ & C & $M$ & $F$ & $\mathrm{R}$ & $\mathrm{R}$ & $\mathrm{R}$ & $\mathrm{R}$ & & $R$ & $\mathrm{R}$ & $F$ & $\mathrm{~F}$ & $C$ & & \\
\hline
\end{tabular}


TABLE 7

Nannofossil Occurrences at Hole 440B

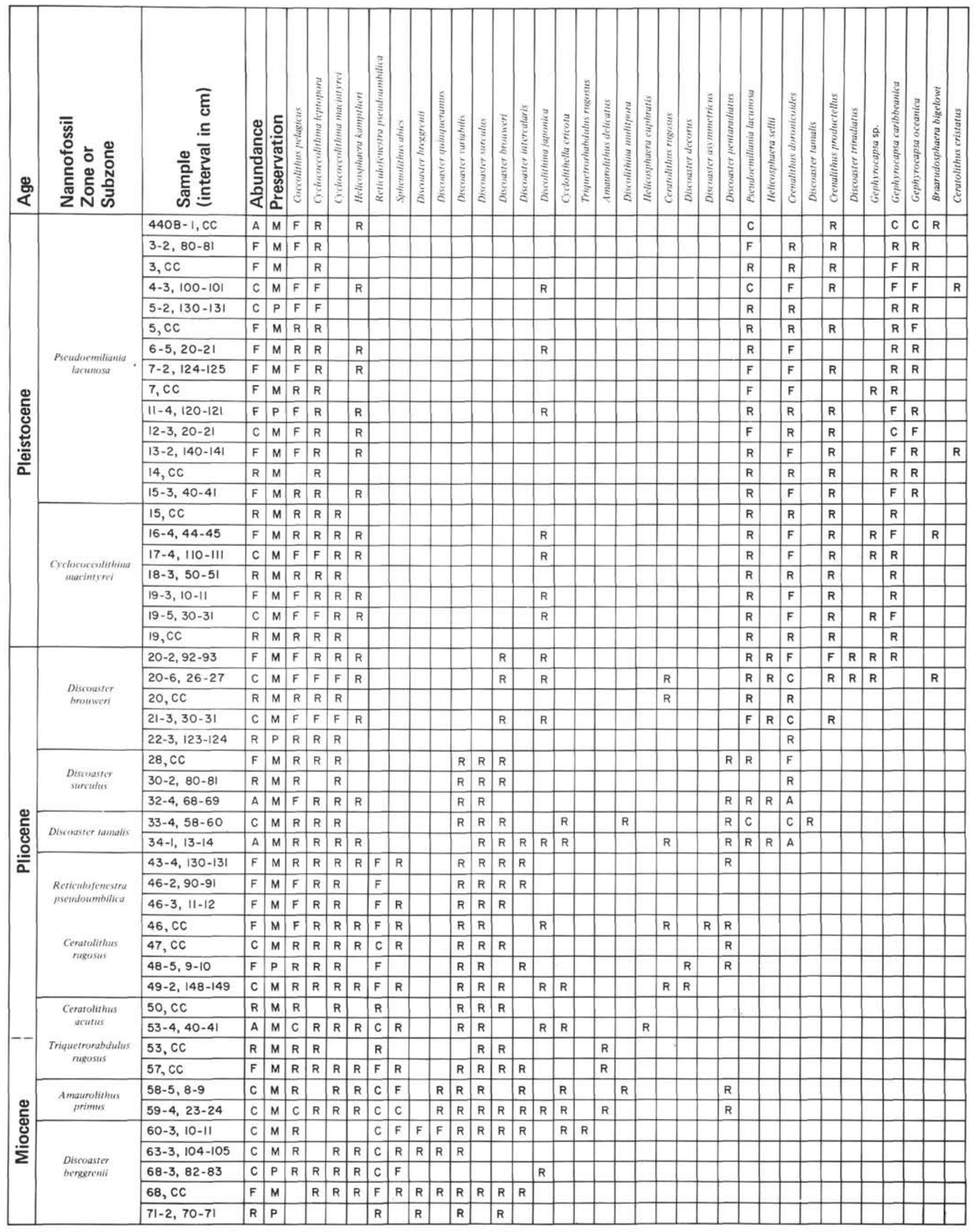

